\title{
1 Future Scenarios of Climate Change Impacts on Fisheries and Aquaculture in Vietnam
}

2 Nhuong Tran ${ }^{1}$, Chin Yee Chan ${ }^{1}$, Yee Mon Aung ${ }^{1}$, Conner Bailey ${ }^{2}$, Michael Akester ${ }^{3}$, Cao Le

3 Quyen ${ }^{4}$, Trinh Quang Tu ${ }^{4}$, Hoang Van Cuong ${ }^{4}$, Timothy B. Sulser ${ }^{5}$ and Keith Wiebe ${ }^{5}$

$5 \quad{ }^{1}$ WorldFish, Penang, Malaysia

$6 \quad{ }^{2}$ Auburn University, USA

$7 \quad{ }^{3}$ WorldFish Myanmar, Myanmar

$8 \quad{ }^{4}$ Vietnam Institute for Fisheries Economics and Planning (VIFEP), Vietnam

$9 \quad{ }^{5}$ International Institute for Policy Research Institute (IFPRI), USA

11 Corresponding author: Nhuong Tran

$12 \quad$ N.Tran@cgiar.org

\section{ABSTRACT}

15 The Vietnamese fisheries sector, including both marine fisheries and aquaculture, has made 16 spectacular progress in recent years, becoming one of the top seafood producing and exporting countries in the world. Looking forward, development goals of this sector must address challenges associated with climate change, including changing distribution of commercially important marine species such as tuna and disruptions to land-based aquaculture production systems. This study investigates the likely impacts of climate change on Vietnam's fisheries sector by exploring plausible future scenarios for four key commodities representing capture fisheries (tuna), freshwater aquaculture (pangasius catfish and tilapia), and brackish water aquaculture (shrimp). The extent of impact varies, but climate change represents a potentially significant threat to sustainable production in each production system. Producers, policy makers, and other stakeholders need to plan for and adapt to climate change to ensure the sustainable development of Vietnam's fisheries sector. This study uses a foresight scenario analysis using a qualitative scenario approach as the starting point for additional modeling of climate change impacts.

Keywords: aquaculture, capture fisheries, climate change impacts, foresight, Vietnam 
Vietnam's fisheries sector has emerged as a dynamic engine of economic growth important both for food security and foreign exchange earnings. Climate change poses an array of challenges to this sector. In this article, we report on foresight analysis efforts designed to help public policymakers and private sector entrepreneurs identify risks associated with increasing climate change impacts on Vietnam's fisheries sector, including marine capture fisheries, freshwater aquaculture, and brackish water aquaculture. Important structural change in Vietnam's economy began in 1986 with the introduction of a market-oriented economy within the context of continued state guidance. Since that time, Vietnam has sustained an average GDP growth rate of over 7\% per year, advancing from one of the poorest countries to one entering the ranks of middle-income countries while dramatically reducing poverty in the process (Baum, 2020). The fisheries sector of Vietnam mirrors these structural changes, with dramatic increases in both marine capture fisheries and aquaculture. In 2018, Vietnam ranked seventh in the world in marine capture fisheries and fourth in aquaculture (FAO, 2020). Vietnam's 2018 seafood exports earned US\$8.9 billion. Seafood available for consumption totaled $37.7 \mathrm{~kg}$ per capita in 2016 and the fisheries sector represented $3.4 \%$ of Vietnam's gross domestic product (FAO, 2021). These figures reflect the growing importance of the fisheries sector in Vietnam not only for export earnings but for income, employment, and food security.

Until recently, marine capture fisheries played a leading role in seafood production in Vietnam. After 2007, however, aquaculture production surpassed that of the marine sub-sector and has expanded its role ever since (Figure 1). Encouraged by international donor agencies, the government of Vietnam has promoted aquaculture as a means of reducing rural poverty while increasing exports (Ha and Bush, 2010). Three species are of particular note in Vietnam's aquacultural development: pangasius catfish, tilapia, and shrimp. Pangasius (Pangasius hypophthalmus) are primarily grown in the Mekong River Delta (MRD) of southern Vietnam using an intensive freshwater production system. Some pangasius producers have shifted to tilapia (Oreochromis niloticus), another freshwater species, which is grown both in the MRD and in the Northern provinces. Shrimp farming in brackishwater coastal mangrove and tidal flats has been centered primarily in the MRD. Initially, shrimp farming involved low-intensity production methods of tiger shrimp (Penaeus monodon) but in recent years, there has been a shift to the whitelegged shrimp (Litopenaeus vannamei) due in part to disease resistance of that species. Lowintensity production systems are still common among small-scale producers in the MRD, but higher intensity production systems (i.e., greater stocking densities and higher feeding rates) have played a role in expanding harvests (Armitage and Marschke, 2013; Gaudreau et al., 2012). Recently, the Vietnamese government passed the National Action Plan for Vietnam's shrimp industry 
development to encourage shrimp farmers to take part in certification systems for the industry, an increasingly important means of ensuring access to the most lucrative international markets (Government of Vietnam, 2018; Tran et al., 2013).

\section{Figure 1 here in text}

Climate change represents a serious challenge to sustaining the growth of Vietnam's fisheries sector. Vietnam is one of the world's most vulnerable countries to global climate change impacts because of its long coastline $(3,260 \mathrm{~km})$ with areas highly susceptible to flooding, and large, densely populated river deltas (Climatelinks, 2017; FAO, 2021). The Intergovernmental Program on Climate Change (IPCC) predicts a mean eustatic (global) sea level rise between $0.43 \mathrm{~m}$ and $0.84 \mathrm{~m}$ by the end of the $21^{\text {st }}$ century (Oppenheimer et al., 2019). Local sea level rise in a deltaic environment may differ from eustatic change due to changes in sediment transport caused by upstream dam construction, subsidence due to groundwater withdrawal, changes in ocean currents, or coastal erosion caused by the removal of mangrove (Douglas, 1997). Most importantly, eustatic sea level estimates do not consider the impact of storm surges associated with tropical typhoons. Much of the area currently devoted to shrimp farming in the MRD would be affected by sea level rise and inundation by storm surges. Significant problems of temporary flooding, salinization of soils and groundwater, and permanent submergence of land are foreseen in the MRD (Carew-Reid, 2008; Doyle et al., 2010). The MRD is also the center for Vietnam's pangasius industry (Belton et al., 2011; De Silva and Phuong, 2011). Pangasius culture is located further from the coast in areas not currently affected by saline intrusion, but sea level rise could change this, causing the industry to move further up-river.

Coastal fishing villages and major fishing ports in the provinces of Hai Phong, Da Nang, Khanh Hoa, and Ba Ria are vulnerable to tropical typhoons and other extreme weather events that can damage or destroy fishing boats and port infrastructure. Beyond that, climate change can affect physical and biological conditions in the marine environment including water temperatures, salinity, and acidification of sea water, all of which can affect habitat (coral reefs, mangrove/estuarine ecosystems) and the growth, development, reproductive capacity, and distribution of marine species (Ahmed et al., 2019; Badjeck et al., 2010; Brander, 2007; 2012; Cooley and Doney, 2009; Doney et al., 2012; Savo et al., 2017).

In this paper, we applied a qualitative strategic foresight approach to provide decision makers the analytic ability to recognize threats, opportunities and trends associated with climate change. This qualitative information will also serve as a foundation for continuing quantitative foresight efforts. Foresight modeling is designed to be an integral part of development planning and resource allocation for an economic sector such as fisheries. Over the years, the Vietnamese government has developed strategies and produced master plans for the fisheries sector, but these strategies and 
104 plans have not benefitted from data and insights based on objective and systematic foresight 105 modeling. Currently, the number of Vietnamese professionals with expertise in strategic forecasting 106 related to the fisheries sector is still limited. The need for foresight modeling today is particularly 107 urgent given that climate change currently is and will continue to affect aquatic resources of all 108 kinds, with serious consequences for the fisheries sector.

109 The qualitative foresight approach we employed here uses expert opinion obtained over the 110 course of two workshops, one conducted in Vung Tau in 2015 and the other in Hanoi in 2019. The 111 workshops were organized by the Vietnam Institute of Fisheries Economics and Planning (VIFEP) 112 and WorldFish and focused on the medium-term future of Vietnam's fisheries sector, including both 113 freshwater aquaculture, brackish water aquaculture and marine capture fisheries. Workshop 114 participants were asked "Under what circumstances and with what policies, could the Vietnamese 115 fishery sector develop sustainably?" This question was explored by examining the factors driving 116 changes in freshwater and brackish water aquaculture and marine capture fisheries, and by 117 evaluating major challenges and opportunities facing the production of key commodities in the 118 Vietnamese fishery sector. The specific contexts required to support sustainable sector development 119 were examined within each scenario. To emphasize the range of pathways that can simultaneously 120 exist, current fishery and aquaculture production systems showing key elements of each scenario 121 trajectory were examined. The scenarios presented in this study were designed to guide discussions 122 that will lead to strategies and policies that support sustainable development within Vietnam's 123 fisheries sector development into the future. The combination of concrete structure, detailed data 124 and fruitful perspectives has significantly contributed to the development of insightful scenarios. 125 One of the essential strengths of scenario exercises rests on the incorporation of creative thinking of 126 participants during the process. During the workshops, participants from diverse institutions with 127 different points of view were encouraged to think creatively and focus on exploring multiple future 128 alternatives beyond a single predicted outcome.

\section{REVIEW ON FORESIGHT AND SCENARIO METHODS}

131 Foresight analysis is an approach that has been widely applied in various fields to study future 132 uncertainties (Cook et al., 2014). Several methods exist to study the future, such as (i) extrapolation 133 of existing trends, (ii) historically-based future studies, (iii) and development of scenarios by 134 various tools, involving horizon scanning, participatory consultation, expert panels, and scenario 135 building (Oborn et al., 2013). Maier et al. (2016) and Borjeson et al. (2006) report that there are 136 three types of scenario development methods), namely (a) predictive scenarios - "what will 137 happen"? (b) exploratory scenarios - "what could happen?", and (c) normative scenarios - "how can 138 a specific future be realized?". The first two scenarios are forward-looking and problem-oriented 
139 (explorations, projections) while the third is solution-focused with a backward view (backcasting).

140 Foresight scenarios are stories communicated using an interdisciplinary approach and providing a 141 narrative explaining how plausible futures might emerge (Raskin et al., 1995). Unlike prediction, 142 projection or forecasting, foresight scenarios are not descriptions of a single result, but rather an 143 exploration of multiple plausible outcomes (Badjecket et al., 2011). Scenarios systematically 144 consider a range of drivers of change and their complex interactions and do so over time. Climate 145 change qualifies as a critical driver of change having the potential to destabilize production in both 146 the aquaculture and marine capture fisheries sub-sectors. The process of change may not be linear 147 as one change may bring on additional changes, creating the possibility of multiple outcomes over 148 time. Simply predicting the course of change based on historical trends is inadequate. Foresight 149 scenarios alert decision-makers to consider unforeseeable changes, enabling them to deal with and 150 plan strategically for whatever the future could bring (Cook et al., 2014).

Oborn et al. (2013) highlight the importance of a scenario development method known as morphological analysis that can be used to identify important issues and support policy formulation 153 by taking into account economic, political, technical, and environmental factors. Other foresight 154 methods such as horizon scanning and scenario planning are used by business and governments for 155 capacity building and long-term strategic planning (Cook et al., 2014). An example of one 156 important foresight scenario narrative relates to nutrition-sensitive aquaculture (Gephart et al., 157 2020). Such scenarios related to the fishery sector help prompt discussions and planning about the 158 kinds of fisheries that are desirable for the future. Forecast scenarios explore knowledge gaps and 159 identify the common problems before suggesting research issues, it can also help to broaden the 160 perspectives and discussions on the future industry. Each scenario developed through various 161 scenario tools holds the potential for contribution to the targeted theme, such as nutrition-sensitive 162 aquaculture (Gephart et al., 2020).

Foresight scenarios take three major forms: quantitative, qualitative, and semi-quantitative. 164 Quantitative methods estimate variables and employ statistical analysis (Popper, 2008). Quantitative 165 foresight modeling is relatively helpful in forecasting systems with well-understood variables over a 166 short period of time but works less well for extended periods when uncertainties are significant and 167 unqualifiable (Cook et al., 2014). Foresight modeling based on qualitative information has been 168 employed to evaluate scenarios in the distant future characterized by increasing uncertainties and 169 complexity. As qualitative scenario planning has the potential to facilitate and structure discussions 170 between stakeholders and scientists about the uncertainties, it can contribute to increased 171 legitimacy, collective learning, and advanced scientific understanding (Rockmann et al., 2012). 172 Qualitative scenario approaches aim to bring research findings together about the inquiry topic from 
a range of experiences, meanings, and perspectives (Barnett-Page and Thomas, 2009). For example, the future of aquaculture in the MRD is not predetermined, but rather exposed to varying forms of natural and human interference the impacts of which are not immediately visible. Qualitative narratives with descriptive richness can effectively illustrate the nature of ambiguity and the variables (quantitative and qualitative) that go into foresight modeling. Efforts to integrate quantitative (e.g., econometric models) and qualitative description are referred to as a semiquantitative approach to scenario building.

Several quantitative models have been developed to support scenario development, including the International Model for Policy Analysis of Agricultural Commodities and Trade (IMPACT) developed by the International Food Policy Research Institute (IFPRI). IMPACT is a partialequilibrium economic model representing a competitive agricultural market for crops and livestock that specifies models for countries, regions, and sub-regions. For the fisheries sector, IFPRI, WorldFish, World Bank, Food and Agricultural Organization (FAO), and the University of Arkansas at Pine Bluff improved the IMPACT fish model based on trends in individual countries and groups of countries for the production of capture fisheries and aquaculture, taking into consideration income, population growth, seafood consumption, and international trade to project global fish supply. To date, several comprehensive foresight modeling reports, including (1) Fish to 2020: Supply and Demand in Changing Global Markets (Delgado et al., 2003); (2) Fish to 2030: Prospects for Fisheries and Aquaculture (World Bank, 2013); (3) Fish to 2050 in the ASEAN Region (Chan et al., 2017), prospects and challenges of fish for food security in Africa (Chan et al., 2019) (4) the OECD-FAO Agriculture Outlook (OECD/FAO, 2017), (5) the CGIAR research portfolio report (Rosegrant et al., 2017), and (6) Fish to 2030: the role and opportunities for aquaculture (Kobayahshi et al., 2015) have been generated to provide regional and global overviews of future fish supply and demand and to provide input for sustainable aquatic food system policies.

Three other models are of importance. The Common Agricultural Policy Regionalized Impact (CAPRI) model and the Global Biosphere Management Model (GLOBIOM) incorporated fish components into their modeling systems (Chang et al., 2018; Latka et al., 2018) and focused on medium or long-term projections at the regional and global levels. A third fish sector model (AsiaFish) developed by Dey et al. $(2005,2016)$ has been used extensively at the country level to evaluate consequences of changes in incomes, urbanization, technology, fishing effort, export prices, trade policy, and impacts of climate change and related adaptation strategies on fish supply and demand in Indonesia and Zambia (Tran et al., 2017, 2019). This model is solved by a Generalized Algebraic Modeling System (GAMS) program to produce a future picture of the fisheries sector at the country level by projecting dynamics of fish supply and demand and drawing 
policy implications based on those projections. Most parameters required for calibrating this model

208 must be estimated from real-life data using econometric methods (Dey et al., 2005) which is 209 difficult in many developing countries. To overcome this challenge, Tran et al. (2019) used the 210 primal approach for production and consumption sectors which is less parameter and data 211 demanding, instead of using the dual modeling approach.

\section{METHODOLOGY}

213 This study has developed future scenarios using a qualitative scenario approach using an 214 exploratory scenario method (Reilly and Willenbockel, 2010). Our scenario activities have 215 progressed through several steps. The scenarios were accepted as the starting ideas to identify 216 knowledge gaps and discuss future demands and emerging research issues (Oborn et al., 2013). 217 Two stakeholder workshops, each consisting of 20-30 invited stakeholders, followed the scenario 218 work.

219 The first step was to engage the core research team in a preliminary literature review, results 220 of which were presented at the beginning of each workshop. The core research team then identified 221 types of stakeholders and stakeholder organizations to participate in the workshops so that diverse 222 experiences and views could be brought together to explore future scenarios on climate change impacts on marine capture fisheries and aquaculture. Two participatory stakeholder consultation workshops were conducted, one in 2015 and the other in 2019. The workshops were organized by WorldFish in collaboration with the International Food Policy Research Institute (IFPRI), and the Vietnam Institute of Fisheries Economics and Planning (VIFEP). Each workshop included 20-30 key stakeholders representing the public and private sectors, industry associations, research institutions, national and international non-profit organizations in Vietnam, and academia. The intent was to involve a wide range of actors whose knowledge and experience would allow them to analyze the socio-environmental issues associated with marine capture fisheries, aquaculture, climate change, economics, and international trade.

In the first workshop conducted in 2015 , an introductory presentation on the importance of the foresight approach and the expected outcomes of this participatory technique to generate qualitative foresight ("scenario") narratives were given. To start the exercise of suggesting drivers of change, participants were first asked to identify past drivers of change that shaped aquaculture in the MRD over the past 10 years. Two professional researchers (workshop facilitators) monitored the discussions. Participants were then divided into groups to identify drivers of change that will likely affect aquaculture in the MRD in the future. Groups were instructed to assign scores from " 1 to 5 " to each driver, based on its impact and level of uncertainty. An impact score of " 5 " represents if a driver of change acts, it would have a significant impact on aquaculture. Similarly, an uncertainty score of " 5 " implies that the likelihood of a driver happening is highly unpredictable. After that, 
242 facilitators assembled the groups to categorize identified drivers of change into different themes.

243 Using the "two-axes" scenario development approach, two critical drivers with the highest impact 244 and uncertainty scores were distinguished to develop a four-quadrant scenario logic for future aquaculture in the next 10-20 years. A representative from each group presented the narrative storyline of the quadrant scenarios that were created.

The second workshop in 2019 stretched over three sessions. In the first session, past and current trends of Vietnam's fishery sector were presented. The second session included a presentation on the scenario development by exploring challenges and opportunities of the Vietnamese fisheries sector, including potential impacts of climate change on the fisheries sector of the future. At this session, participants were asked to identify research priorities for fisheries development by sub-sector (capture fisheries and aquaculture) and by commodities (tuna, pangasius, shrimp, and tilapia). Workshop facilitators monitored workshop activities to ensure constructive discussion and then encouraged participants to investigate new possibilities, come up with imaginative ideas and promote a broader view of fishery sector development in the context of climate change impacts. Finally, global climate change and its potential impact on fisheries and aquaculture and analysis of the vulnerability of aquaculture to climate change in Vietnam were presented. Participants were then grouped to draw up development scenarios for marine capture fisheries and aquaculture and examine the likely impact of climate change on key commodities.

\section{RESULTS}

\section{Past and Current Trends of Vietnamese Capture Fisheries and Aquaculture Sector}

263 Vietnam's fisheries sector plays an important role in rural and agricultural development and is of 264 increasing significance for the country's economy in general. Over the past 20 years, Vietnam's 265 fisheries sector has experienced rapid production growth, increasing from 1.34 million MT in 1995 to 7.74 million MT in 2018, a nearly six-fold increase in 23 years (Figure 1). By 2007, aquaculture production had surpassed harvests from capture fisheries in total production, accounting for 54 percent of the total by 2018. The fisheries sector has made substantial contributions to rural restructuring through poverty reduction and job creation - nearly five million workers are employed in different segments of the fisheries and aquaculture value chains.

\section{Capture Fisheries Production}

273 On a global basis, harvests from marine capture fisheries have been stagnant, but this is not so for 274 Southeast Asia in general or Vietnam. According to the General Statistics Office (GSO) and the 275 Directorate of Fisheries (2018), Vietnam's capture fisheries output tripled from 929,000 MT in 1995 to 3,590,000 MT in 2018. Of this total, 94\% came from marine fisheries with the remaining 
harvest coming from inland waters. Data on marine capture fisheries were reported for four regions, including the Gulf of Tonkin, the Central and South-Eastern regions, and the MRD. Even as landings of fish increased, the relative share of landings between these four regions remained remarkably constant (Figure 2). Of marine capture fisheries output, tuna harvests (primarily skipjack and yellowfin) were reported at 16,650 MT (Directorate of Fisheries, 2018).

Figure 2 here in text

\section{Aquaculture Area and Production}

Aquaculture has been practiced in Vietnam for centuries using low-intensity "traditional" production methods. A shift towards more intensive systems began in the 1960s but the real change came after the year 2000 when the Vietnamese government encouraged farmers to convert low productivity saline rice fields, uncultivated areas, and salt pans in the coastal zone into brackish water ponds for aquaculture (The Government of Vietnam Resolution No.09/2000/NQ-CP of June 15, 2000). This new policy encouraged private sector investment in both production and processing facilities. Public sector infrastructure investments also were made. Between 1995 and 2018, aquaculture production in Vietnam increased by more than 10 times, from 415,000 MT to 4,153,000 MT, with most of this gain coming since 2000 (Directorate of Fisheries, 2017; GSO, 2018). Finfish and shrimp accounted for $70 \%$ and $19 \%$, respectively, of total production.

A total of 1.1 million hectares are devoted to aquaculture in Vietnam, with brackish water ponds accounting for two-thirds of the total and dedicated almost exclusively to shrimp production (Directorate of Fisheries, 2018). As can be seen in Figure 3, between 2000 and 2018, total aquaculture production increased at a far higher rate than the area under production. Eighty percent of shrimp production in Vietnam occurs in the MRD (MARD, 2019) where it has contributed significantly to economic development for hundreds of thousands of small-scale producers (Jo et al., 2019; Tran et al., 2013). Vietnam ranks third in the world for volume of farmed shrimp production (FAO, 2018), generating US\$ 3.7 billion in export value in 2020 (MARD, 2021). The MRD also is the center for aquaculture production of finfish, notably pangasius. The area devoted to pangasius production is relatively small (5,200 hectares) but the methods employed are highly intensive and yield production totaling 1.25 million MT, accounting for nearly half of all finfish production nationwide (Directorate of Fisheries, 2018).

\section{Figure 3 here in text}

The concentration of aquaculture production in the MRD creates significant vulnerability to climate change and particularly to the combination of extreme weather events and sea level rise (Hallegatte et al., 2013). On average, Vietnam is hit by typhoons four to six times a year, bringing high winds, heavy rainfall, and storm surges that destroy homes and infrastructure, and frequently 
311 lead to human fatalities. Tropical storms that do not reach typhoon intensity may also cause damage

312 to infrastructure and production facilities and flooding of shrimp ponds. Storm surges combined 313 with projected sea level rise of half a meter or more in the decades to come threaten large parts of 314 the MRD. This problem is compounded by the construction of numerous dams along the course of 315 the Mekong Delta, which have the effect of reducing the river's sediment load and starving the delta 316 of new building material (Elyer, 2020). Vietnam's Directorate of Fisheries (2017) has warned that 317 climate change is likely to have an impact on the fisheries sector.

\section{Fish Market and Trade}

320 Since 2014, Vietnam has maintained its position as the third largest exporter of seafood in the world 321 by value, followed only by China and Norway (FAO, 2020). In 2018, total export earnings from the 322 fisheries sector reached US\$8.8 billion, nearly twice the value of exports in 2010 (Vietnam 323 Association of Seafood Exporters and Producers, 2018). The main importers included the United 324 States (US\$1.6 billion), the European Union (US\$1.5 billion), Japan (US\$1.4 billion), and China 325 (US\$1.2 billion). South Korea and other nations of Southeast Asia are emerging as promising 326 markets. Shrimp (US\$3.6 billion), pangasius (US\$2.3 billion), cephalopods (US\$672 million), and tuna (US\$653 million) were the main export products.

Vietnam's success in seafood exports is based not only on production within the fisheries sector but also on significant improvements in the seafood processing capacity and quality (Do et al., 2019; Kagawa and Bailey, 2006). Strict food safety requirements for export products represent significant obstacles for the hundreds of thousands of small-scale shrimp producers and the smallscale traders who buy shrimp at the farm (Tran et al., 2013). In many if not most cases, neither the producer nor the trader keeps the kind of records necessary for proof of origin tracing used in seafood certification programs. Organizing hundreds of thousands of small-scale producers and traders in a way to meet certification standards is a huge challenge. Access to the most profitable international seafood markets requires that strict food safety standards be met, including the absence of anti-biotic residues. A variety of certification programs (e.g., Marine Stewardship Council and the Aquaculture Stewardship Council) have additional standards that address sustainability and social justice, among other issues. Obtaining certifications provides access to markets that pay price premiums but is not realistic options for individual farmers operating a one-hectare pond. Tran et al. (2013) suggested that organized groups of small-scale producers and processors could work together and gain mutual benefits - small-scale producers could receive a premium price while the processors could promote their product as supporting small-scale farmers. At present, however, most of the benefits from higher prices brought by certification programs have been captured either by processors who operate their own shrimp farms or by a small number of well-capitalized shrimp 
producers who manage their farms with higher levels of inputs and productivity than is possible among small-scale farmers.

\section{Future Scenarios of Climate Change Impacts on Key Fishery Commodities}

This section starts by describing the various ways Vietnam's fisheries and aquaculture sector is vulnerable to climate change. We then forecasted the likely effect of climate change on the production of four key commodities. In this discussion, marine capture fisheries were represented by tuna while pangasius catfish, tilapia, and shrimp represented freshwater and brackish water aquaculture.

Based on climate change projections published in 2007 by the IPCC and indicators of exposure, sensitivity, and adaptive capacity covering the period 1989-2014, Quyen et al. (2019) developed a vulnerability index (VI) for aquaculture in all 698 districts of 63 provinces in Vietnam. As shown in Figure 4, fish farming was at medium or high vulnerability levels throughout the country. Shrimp farming was identified as being even more vulnerable (Figure 5). In both cases, parts of the MRD scored highly on the vulnerability index. Kam et al. (2015) reported similar findings of widespread vulnerability, including in the MRD where aquaculture production is concentrated.

\section{Figures 4 and 5 here in text}

The studies by Kam et al. (2015) and Quyen et al. (2018) have used both social and physical indicators to estimate vulnerability to climate change. In these studies, vulnerability estimates of the aquaculture sector in the MRD have been reduced due to investments in local infrastructure as well as poverty alleviation programs supported by both local government and international/national agencies. These studies also relied on data for current levels of vulnerability and do not project into the future. Foresight modeling requires looking into the future, and for our purposes, this involves estimates of temperature, rainfall, and sea level rise from now to the end of the current century.

Minderhoud et al. (2019) examined elevations in meters above mean sea level for the MRD. Their findings showed $29 \%$ of the MRD would be inundated by a sea level rise of $50 \mathrm{~cm}$, and this figure would increase to $54 \%$ with a rise of $80 \mathrm{~cm}$. Sea level rise of one meter would submerge lands currently occupied by 12 million people, $70 \%$ of the MRD's population. The western MRD facing the Gulf of Thailand is the area that will first experience inundation due both to eustatic sea level rise and to land subsidence caused by sedimentation and withdrawal of freshwater for domestic purposes (IPCC, 2007; Thuc et al., 2016). Sea level rise of $80 \mathrm{~cm}$ could inundate a substantial area of shrimp farming and a one-meter rise would threaten pangasius production areas along the various courses of the Mekong River (Kam et al., 2012). Previous studies indicated the 
380 Red River Delta in northern Vietnam also is vulnerable to inundation due to sea level rise (Carew381 Reid, 2008).

382 In addition to sea level rise, climate change may affect maximum temperatures and rainfall 383 patterns. Over the past 50 years, rainfall has increased by $5-20 \%$ in the South but decreased by 5 $38410 \%$ in the North (Vietnam Institute of Meteorology, Hydrology and Climate Change, 2010). 385 Climate change could contribute to an increase in extreme weather events, droughts, and changes in 386 salinity affecting estuarine and coastal environments. These changes could affect the reproductive 387 success of crustacean and finfish species. Protecting some coastal areas from sea level rise is 388 technically possible but protecting thousands (or even hundreds) of kilometers of coastline is not a 389 likely scenario. There are engineering solutions to some problems associated with extreme weather, 390 flooding, and other problems, but the broader environmental impacts of climate change will require 391 adaptive management within the fisheries sector designed to mitigate problems forecast to occur 392 decades in the future. In the sections, which follow, we examined the likely impacts of climate 393 change on tuna capture fisheries freshwater aquacultural production of pangasius and tilapia, and 394 brackish water production of shrimp.

\section{Tuna}

396 Vietnam has a long coastline and an Exclusive Economic Zone of more than 1 million $\mathrm{km}^{2}$. Tuna 397 species are important to Vietnam's capture fisheries sector, with 2018 landings of skipjack tuna 398 totaling 91,461 MT followed by yellow-fin tuna (25,455 MT) and big eye tuna (3,618 MT) (FAO, 399 2018). Climate change affects water temperature and the distribution of prey species and therefore 400 tuna species (Quyen et al., 2017). Intensified wind and wave action are likely consequences of 401 ocean warming, as are increases in the number and intensity of tropical typhoons that damage both 402 fishing boats and coastal infrastructure important to tuna and other capture fisheries such as cold 403 storage, processing, and transportation facilities (CCSP, 2008). Changes in ocean temperature also 404 can affect dissolved oxygen concentrations, ocean circulation and upwelling that brings nutrients 405 from the seafloor to the surface, thereby increasing primary productivity (e.g., phytoplankton and 406 zooplankton) that supports marine food webs where tuna are apex predators. In addition, rising 407 temperatures are associated with increased ocean acidification, particularly in surface waters (FAO, 408 2009). Acidification has the potential to disrupt primary productivity and adversely affect the 409 reproductive success of both vertebrates (e.g., tuna and prey species) and invertebrates (e.g., 410 phytoplankton and zooplankton) by harming eggs and larvae at vulnerable life stages.

411 No detailed studies of how climate change affects tuna species in Vietnam's waters are 412 available, but studies in the Pacific Ocean provided a starting point for understanding. Changes in 413 ocean temperature drive atmospheric and hydrological cycles. The El Niño-Southern Oscillation 
414 (ENSO) phenomenon is a recurring climate pattern involving the warming and cooling of tropical 415 waters in the central and eastern Pacific Ocean and has been shown to impact the location and stock 416 sizes of Pacific tuna fisheries. Warmer El Niño conditions favor an increase in skipjack abundance, 417 with a spatial shift in an easterly direction while the cooler La Niña phase results in a shift of 418 skipjack tuna populations to the west (Guidry and Mackenzie, 2013; Lehodey et al., 2010; 2011). 419 Within Vietnam's Exclusive Economic Zone, it is likely that the movement of skipjack and other 420 tuna species will gradually move away from the equator (i.e., to the north). Dueri et al. (2014) 421 projected a deterioration of skipjack habitat in most tropical waters and an improvement of habitat 422 at higher latitudes. The primary driver of habitat changes is ocean warming, followed by food 423 density (prey species) changes. Globally, the model used by Dueri et al. (2014) showed an increase 424 in global skipjack biomass between 2010 and 2050 followed by a marked decrease between 2050 425 and 2095. A more recent study published by Senina (2018) confirmed these results and extends 426 them to include yellowfin tuna.

Climate change is likely to lead to changes in tuna distribution and abundance, though the changes will be gradual rather than abrupt. Most of the available research has focused on skipjack tuna, but there is no reason to expect fundamental predator/prey relationships would be different for other tuna species. Currently, tuna are landed by wooden-hulled vessels using longlines off the coast of central and northern Vietnam (Urch, 2016). Warming ocean temperatures will tend to drive tuna stocks in a northerly direction towards China, a movement that may reduce access to these stocks by Vietnamese fishers. Increased rainfall will change the $\mathrm{pH}$ at the ocean surface and affect salinity, particularly near major river deltas. These changes could affect the reproductive success of prey species tuna depend upon. Climate change also can lead to increased frequency and severity of typhoons and tropical storms, affecting the ability of fishermen to operate in heavy seas or travel greater distances in search of tuna. All these factors may adversely affect the fortunes of Vietnam's tuna fisheries. The growth and increasing sophistication of Vietnam's seafood processing industry may result in tuna caught by fleets from other countries being landed in Vietnam for processing and re-export.

442 The total production of pangasius catfish in 2018 was 1.42 million MT from ponds with a total area 443 of 5,200 hectares (Directorate of Fisheries, 2018). Between 2014 and 2018, the total area devoted to 444 pangasius production has remained relatively constant while overall productivity has shown a 445 gradual increase, achieving a level of $273 \mathrm{MT} / \mathrm{ha}$ in 2018. As noted above, pangasius production is an important source of foreign exchange earnings. 
through the MRD. Typhoons that affect the MRD often occur in November and are a source of flooding risk. Other tropical storms and the possibility of increasingly heavy rainfall could lead to frequent flooding, erosion of pond dikes, damage to farm facilities, fish disease problems with higher turbidity levels and lowered $\mathrm{PH}$, and escapes of fish from ponds inundated by flood-waters. Sea level rise and episodic storm surges associated with typhoons and other tropical storms can push saline water from estuaries further into the interior, resulting in the loss of production area. This latter threat can be addressed by moving production facilities further upstream.

Based on Global Climate Models (GCM) and Providing Regional Climates for Impacts Studies (PRECIS) climate model by Jones et al. (2003), temperatures in the MRD between Ca Mau Province and Ho Chi Minh City are projected to increase by $1{ }^{\circ} \mathrm{C}$ in 2050 and between $1.4^{\circ} \mathrm{C}$ to as much as $2.7^{\circ} \mathrm{C}$ by the year 2100 . Climate change in the MRD also will affect seasonal rainfall patterns, increasing rainfall during the rainy season and reducing rainfall during the dry season. Temperature increases and changes in the hydrological system supporting pangasius production will affect fish growth due to stress, increasing the possibility of viral or bacteriological disease. These changes are likely to have significant economic impacts not only on producer income (Kam et al., 2010) but affect other actors in the value chain, including input suppliers (hatcheries, feed, and equipment), processors, and exporters.

Expert workshop participants were optimistic that current levels of pangasius production can be maintained due to existing expertise and the ability to adopt new technologies. Through selective breeding, Vietnam has replaced the original brood-stock established in the 1990s with a third generation of fish adapted to local conditions. This has given experts in Vietnam confidence that the industry will be able to adapt to changing climate conditions over the next several decades. There are external challenges that must be considered. Dam construction on the upper reaches of the Mekong River (i.e., in China and Laos) basin may change hydrological conditions in the MRD. The range of areas suitable for pangasius production is likely to expand northward. In Vietnam, this means the Red River delta may come to play a larger role in Vietnam's pangasius production. China may come to play a more dominant role in pangasius production, increasing competition in international markets.

\section{Tilapia}

Tilapia production in Vietnam has grown steadily since 2010 with the success in breading mono-sex tilapia, reaching 225,000 MT coming from 30,000 hectares of ponds. Currently, tilapia is mostly grown in northern Vietnam and in particular Bac Giang, Bac Ninh, Hai Duong, Quang Ninh, Thai Binh, and Thanh Hoa provinces. Compared to the technological sophistication developed around 
pangasius production, tilapia producers in Vietnam still have considerable room for improvement. One incentive for doing so is the government's desire to promote tilapia as an export commodity.

Like pangasius, which dominates the MRD of Vietnam's south, tilapia production in the north can be affected by climate change. Rising temperatures can slow growth and decrease production (FAO, 2009). Climate models projected temperatures in northern Vietnam to increase more rapidly than in the south. For the north, temperatures are expected to increase by $1.2^{\circ} \mathrm{C}$ $1.3^{\circ} \mathrm{C}$ by 2050 , with even greater increases $\left(1.4^{\circ} \mathrm{C}-1.5^{\circ} \mathrm{C}\right)$ for the north central coast. Similarly, for rainfall, by 2050 northern Vietnam may experience an increase of precipitation between $3.8 \%$ to $10.1 \%$. A $10 \%$ increase spread out over the course of a year would create few problems, but increases may come in short bursts with disruptive potential. As with pangasius production in the south, increased temperatures and rainfall in northern Vietnam can result in damage to ponds and other productive infrastructure and flooding, resulting in fish escapes. Saline intrusion associated with sea level rise will affect tilapia production in coastal areas where pumping groundwater is important to the system.

In the near term, climate change is unlikely to have major impacts on tilapia production in Vietnam. To the extent that barriers to trade between China and the United States continue to exist, opportunities for Vietnam to replace China as a source of tilapia to international markets might spur further development. The consensus of workshop participants was that toward the end of the 2020s and beyond, climate change will begin to disrupt tilapia production due to temperature fluctuations, increased rainfall, and coastal inundation. Competition in international seafood markets will remain intensive and may increase as new actors enter the field.

\section{Shrimp}

Two species of shrimp account for most production in Vietnam: the white-leg shrimp (Litopenaeus vannamei, 475,000 MT in 2018) and black tiger shrimp (Penaeus monodon, 270,000 MT in 2018; FAO, 2021). A total of 700,000 hectares are devoted to shrimp farming, mostly in the MRD. Shrimp from Vietnam are exported around the world. In 2018, the Government of Vietnam announced plans to expand shrimp exports to US\$10 billion by 2025 by the promulgation of Decision No. 79/QD-TTg of the Government on January 18, 2018 (Government of Vietnam, 2018).

Research on the impact of climate change on shrimp production has focused on sea level rise, increasingly erratic weather, and higher temperatures and rainfall. Research by Te (2003) and Quyen et al. (2018) has shown that elevated temperatures adversely affect shrimp growth due to stress and increase mortality due to problems of water quality and disease. Weather fluctuations will contribute to stress on the shrimp themselves, heavy rainfall could lead to salinity in ponds to drop 
516 to sub-optimal levels. As with all other species raised in ponds, the threat of flooding and mass

517 escapes is a serious concern. Many shrimp ponds in the MRD are barely above sea level so flooding 518 from storm surges from tropical storms and typhoons is a serious risk in many areas. Sea level rise 519 in the decades to come will force some shrimp farmers to abandon their ponds. In the MRD, much 520 of the transportation network is on waterways, so flooding, storm surges, and sea level rise is not so 521 disruptive as are these phenomena on roads and other land-based infrastructure. Where roads and 522 bridges are found, these will be increasingly vulnerable to flooding and may need elevation. Many 523 shrimp processing plants are as little as $0.5 \mathrm{~m}$ above sea level and most are under $1.5 \mathrm{~m}$. These 524 facilities are critical to the shrimp industry and are vulnerable to sea level rise and storm surges. 525 Parts of Ho Chi Minh City routinely flood when heavy rain and high tides coincide.

\section{DISCUSSION}

528 Through two stakeholder consultation workshops, national and international experts were brought 529 together to discuss a range of different adaptations to climate change within Vietnam's fisheries 530 sector, explicitly including both marine capture fisheries and aquaculture. This consultation 531 provided the basis for this preliminary foresight modeling and scenario planning effort designed to 532 identify alternative pathways and options to inform resource management and development 533 planning. The ability to project future scenarios will increase the ability of policy makers and 534 private sector investors to prepare in advance and mitigate disruptions caused by rising 535 temperatures, increasing precipitation, rising sea levels, and increasingly severe weather events 536 including tropical storms, typhoons, and attendant flooding. On a daily basis in the future, climate 537 change is likely to have dramatic impacts on hydrologic conditions, including storm surges, 538 salinization of coastal aquifers, intrusion of saline water further upstream, and coastal erosion. 539 These impacts are likely to have profound impacts on aquacultural production systems vulnerable to 540 changes in water quality, $\mathrm{pH}$, and salinity, and to near total loss of fish or shrimp in the event of 541 inundation. The marine capture fisheries sub-sector is vulnerable to storm damage affecting boats, 542 harbors, and other infrastructure, and to spatial shifts of commercially important species associated 543 with increasing ocean temperatures.

544 Vietnam's fisheries sector has experienced dramatic production increases, improving both 545 national food security and generating significant foreign exchange earnings. As described here, 546 climate change represents a serious challenge to the fisheries sector in the future. These challenges 547 are best met through advanced preparation, projecting future scenarios and planning strategies to 548 mitigate or overcome the challenges. Modeling the impact of multiple factors associated with 549 climate change on development within the fisheries sector can provide policy makers the 550 information necessary to set policies to manage resources for long-term sustainability, and to 
551 balance food and nutrition security for poor and vulnerable populations with international trade 552 goals. This information is also of importance to private sector investors in infrastructure, 553 production, and processing facilities.

554 The Government of Vietnam has recognized the importance of improving forecasting and scenario development capacity. Scientists and fisheries managers in Vietnam have reached out to international partners, notably WorldFish and IFPRI to support capacity building in this arena. As the research highlights the importance and usefulness of the quantitative foresight modeling tools as mentioned above, these modeling tools would be a useful tool to support the Vietnamese fisheries sector's planning and revision. Successful adoption of the IMPACT model and fish sector model for

560 foresight modeling and scenario planning will require technical and financial support from donors, 561 CGIAR research centers (IFPRI and WorldFish), universities, and other partners with the requisite technical skills.

One challenge to effective modeling is the quality of statistical data available to modelers. Such challenges cannot be overcome overnight, and commitment to this goal from top levels of the national government will be necessary. A second challenge to effective scenario development is understanding the highly dynamic nature of international markets for seafood. Vietnam has become a major exporter, particularly of shrimp and pangasius catfish. These markets are highly competitive, and while climate change poses many challenges, competition in the marketplace adds a new dimension with significant implications for the economic health of the fisheries sector. Recognizing the need for adopting quantitative foresight models, as demonstrated here, a qualitative foresight approach has value though incorporating data that are not easily quantifiable, drawing on expert opinions in a setting of open discussion, and bringing to the discussions a wide range of stakeholders. This paper is the product of such discussions and provides a basis both for decision makers to set policy and make investment decisions, and for building a foresight modeling effort that combines both qualitative and quantitative models.

\section{CONCLUSION}

Vietnam's fisheries sector currently makes an important contribution to employment, livelihoods, food security, and export earnings. The multi-faceted challenges of climate change for marine fisheries, freshwater aquaculture, and brackish water aquaculture required well-designed policies and sector development planning. Despite these challenges, we believe it fair to say that adaptation to climate change has not yet achieved the level of policy primacy as has increased production and export earnings. Given the increasing challenges that climate change will pose for Vietnam's fisheries sector in the years ahead, foresight modeling and analysis will provide critically important information to policymakers and private sector investors. Investments in strengthening data 
585 collection and both quantitative and qualitative foresight modeling capacity will pay dividends for 586 decades to come.

\section{ACKNOWLEDGMENTS}

This work was implemented as part of the CGIAR Research Programs on Climate Change, Agriculture and Food Security (CCAFS), which is carried out with support from the CGIAR Trust

Fund and through bilateral funding agreements (For details please visit 592 https://ccafs.cgiar.org/donors). Funding support for this study was also provided by the CGIAR 593 Research Program on Fish Agri Food Systems (FISH) and by the CGIAR Research Program on 594 Policies, Institutions, and Markets (PIM). The views expressed in this document belong to the authors and do not necessarily reflect those of CCAFS, FISH or PIM.

\section{REFERENCES}

Ahmed, I., Ayeb-Karlsson, S., Van der Geest, K., Huq, S., and Jordan, J. C. (2019). Climate 599 change, environmental stress and loss of livelihoods can push people towards illegal activities: A case study from coastal Bangladesh. Clim. Develop. 11:907-917.

Armitage, D., and Marschke, M. (2013). Assessing the future of small-scale fishery systems in coastal Vietnam and the implications for policy. Environ. Sci. Poli. 27:184-194.

Badjeck, N.-C., Allison, E. H., Halls, A. S., and Dulvy, N.K. (2010). Impacts of climate variability 604

Barnett-Page, E., and Thomas, J. (2009). Methods for the synthesis of qualitative research: a critical review. BMC Med. Res. Method. 9 (1), 59.

Baum, A. (2020). Vietnam's development success story and the unfinished SDG agenda. International Monetary Fund (IMF) working paper. Asia Pacific Department.

Belton, B., Little, D. C., and Sinh, L. X. (2011). The social relations of catfish production in Vietnam. Geoforum. 42(5):567-577.

Börjeson, L., Höjer, M., Dreborg, K.-H., Ekvall, T., and Finnveden, G. (2006). Scenario types and techniques: towards a user's guide. Futures 38 (7), 723-739.

Brander, K. (2007). Global fish production and climate change. PNAS .104:19709-19714.

Brander, K. (2012). Climate and current anthropogenic impacts on fisheries. Clim. Chan. 119: 9-21. 
Carew-Reid, J. (2008). Rapid assessment of the extent and impact of sea level rise in Viet Nam. Climate Change Discussion Paper 1, February 2008. Brisbane, Australia: International Centre for Environmental Management.

CCSP. (2008). Weather and climate extremes in a changing climate. Regions of focus: North America, Hawaii, Caribbean, and U.S. Pacific Islands. U.S. Climate Change Science Program. Synthesis and Assessment Product 3.3.

Chan, C.Y., Tran, N., Dao, C.D., Sulser, T. B., Phillips, M. J., Batka, M., Wiebe, K. D., and Preston, N. (2017). Fish to 2050 in the ASEAN region. Penang, Malaysia: Worldfish and Washington DC. International Food Policy Research Institute (IFPRI), USA (Working Paper: 2017-01).

Chan, C.Y., Tran, N., Pethiyagoda, S., Crissma, C. C., Sulser, T. B., and Phillips, M. J. (2019). Prospects and challenges of fish for food security in Africa. Glob. Food. Secu. 20. https://doi.org/10.1016/j.gfs.2018.12.002

Chang, C.Y., Witzke, H. P., and Latka, C. (2018). A model for data consolidation of the fish market in Capri. In: Proceedings of the 58th Annual Conference on German Association of Agricultural Economists (GEWISOLA), Kiel, Germany, September 12-14, 2018. http://ageconsearch.umn.edu/record/276013/files/2191. pdf

Climatelinks. (2017). Climate risk profile: Vietnam. January 9, 2017. Washington, D.C. U.S. Agency for International Development. https://www.climatelinks.org/resources/climaterisk-profile-vietnam

Cook, C.N., Inayatullah, S., Burgman, M., Sutherland, W.J., and Wintle, B.A. (2014). Strategic foresight: how planning for the unpredictable can improve environmental decision-making. Trends in Ecol. Evolu. 29(9):531-541. 10.1016/j.tree.2014.07.005

Cooley, S.R., and Doney, S.C. (2009). Anticipating ocean acidification's economic consequences for commercial fisheries. Environ. Resear. Let. 4024007.

Delgado, C.L., Wada, N., Rosegrant, M. W., Meijer, S., and Ahmed, M. (2003). Fish to 2020: Supply and demand in changing global markets. WorldFish Center Technical Report. International Food Policy Research Institute, Washington, DC, pp. 62.

De Silva, S.S., and Phuong, N.T. (2011). Striped catfish farming in the Mekong Delta, Vietnam: a tumultuous path to a global success. R. in Aqua. 3(2):45-73.

Dey, M.M., Briones, R. M., and Ahmed, M. (2005). Disaggregated analysis of fish supply, demand, and trade in Asia: baseline model and estimation strategy. Aqua. Econ. Manag. 9:113-139.

Dey, M.M., Rosegrant, M. W., Gosh, K., Chen, O. L., and Valmonte-Santos, R. (2016). Analysis of the economic impact of climate change and climate change adaptation strategies for fisheries 

sector in Pacific coral triangle countries: model, estimation strategy, and baseline results. Mari. Poli. 67:156-163.

Directorate of Fisheries. (2017). Statistics of the fisheries sector in the period of 2013-2017. Hanoi: Directorate of Fisheries.

Directorate of Fisheries. (2018). Report on fisheries achievement in 2018 and plan for 2019. Hanoi: Directorate of Fisheries.

Directorate of Fisheries. (2019). Report on fisheries achievement in 2019 and plan for 2020. Hanoi: Directorate of Fisheries.

Do, B., Uyen, N., Ninh, N., and Johnson, L. W. (2019). Exploring the proactivity levels and drivers of environmental strategies adopted by Vietnamese seafood export processing firms: A qualitative approach. Sustain. 11(14), $3964 . \quad$ https://www.mdpi.com/2071$1050 / 11 / 14 / 3964$ doi:10.1080/13657305.2015.994240

Doney, S.C., Ruckelshaus, M., Duffy, J. E., Barry, J. P., Chan, F., English, C.A., Galindo, H. M., Grebmeier, J.M., Hollowed, A. B., Knowlton, N., Polovina, J., Rabalais, N. N., Sydeman, W. J., and Talley, L.D. (2012). Climate change impacts on marine ecosystems. Ann. R. Mari. Sci. 4:11-37.

Douglas, B.C. (1997). Global sea rise: a redetermination. Surv. in Geoph. 18(203):279-292.

Doyle, T.W., Day, R.H., and Michot, T.C. (2010). Development of sea level rise scenarios for climate change assessments of the Mekong Delta, Vietnam. U.S. Geological Survey OpenFile Report 2010-1165. Lafayette, LA: USGS National Wetlands Research Center. Accessed on 13 September 2013. Available at http://pubs.usgs.gov/of/2010/1165/downloads/OF10-1165.pdf.

Dueri, S., Bopp, L., and Maury, O. (2014). Projecting the impacts of climate change on skipjack tuna abundance and spatial distribution. Glo. Chan. Bio. 20:742-753.

Eyler, B. (2020). Science shows Chinese dams are devastating the Mekong. Forei. Poli. April 22, 2020. https://foreignpolicy.com/2020/04/22/science-shows-chinese-dams-devastatingmekong-river/

FAO (Food and Agriculture Organization). (2009). The state of the world's fisheries and aquaculture 2009. Food and Agriculture Organization, Rome.

FAO (Food and Agriculture Organization). (2018). Fisheries and aquaculture information and statistics branch. (https://www.fao.org/figis/servlet/SQServlet?file=/usr/local/tomcat/8.5.16/figis/webapps/figi s/temp/hqp_5975613468110294818.xml\&outtype=html) 
FAO (Food and Agriculture Organization). (2020). The state of world fisheries and aquaculture 2020. Sustainability in Action. Rome. https://doi.org/10.4060/ca9229en

FAO (Food and Agriculture Organization). (2021). GLOBEFISH Market Profile - 2018, Vietnam. Country Brief. June 2021. Rome. http://www.fao.org/3/cb5899en/cb5899en.pdf

Gaudreau, M., Schut, L., and Wilkings, A. (2012). Fisheries transitions in Vietnam: A Path Towards (Un)sustainability. Working Paper Number 1. https://melissamarschke. files.wordpress.com/2012/02/fisheries-transitions-in-vietnam_final.pdf.

General Statistics Office. (2018). Statistical handbook of Vietnam 2018. Hanoi: Government of Vietnam Statistical Publishing House.

Gephart, J.A., Golden, C.D., Asche, F., Belton, B., Brugere, C., Froehlich, H.E., Fry, J.P., Halpern, B.S., Hicks, C.C., Jones, R.C., Klinger, D.H., Little, D.C., McCauley, D.J., Thilsted, S.H., Troell, M., and Allison, E.H. (2020). Scenarios for global aquaculture and its role in human nutrition. Rev. in Fish. Sci. Aqua. https://doi.org/10.1080/23308249.2020.1782342

Government of Vietnam. (2018). National action plan to develop Vietnam's shrimp industry to 2025 (Decision No. 79/QĐ-TTg dated 18/01/2018), Hanoi, Vietnam.

Guidry, M.W., and Mackenzie, F.T. (2013). Future climate change, sea-level rise and ocean acidification: Implications for Hawaii and Western Pacific Fisheries Management. University of Hawaii Sea Grant. 42-46.

Ha, T.T.T., and Bush, S.R. (2010). Transformation of Vietnamese shrimp aquaculture policy: empirical evidence from the Mekong Delta. Environ. Plan. C: Govern. Poli. 28, 1101-1119. DOI: $10.1068 / \mathrm{c} 09194$

Hallegatte, S., Green, C., Nicholls, R. J., and Corfee-Morlot, J. (2013). Future flood losses in major coastal cities. Nat. Clim. Chan. 3(9):802-806. DOI: 10.1038/nclimate1979 https://www.fao.org/fileadmin/user_upload/common_oceans/docs/Final-reportPacificTunaClimateChange.pdf.

IPCC. (2007). Summary for policymakers. In: climate change 2007: Impacts, adaptation and vulnerability. Contribution of Working Group II to the Fourth Assessment Report of the Intergovernmental Panel on Climate Change, Parry M.L., Canziani O.F., Palutikof J.P., van der Linden P.J., and Hanson C.E., Eds., Cambridge University Press, Cambridge, UK, 7-22.

Jo, O.M., Poortvliet, P. M., and Klerkx, L. (2019). To cluster or not to cluster farmers? Influences on network interactions, risk perceptions, and adoption of aquaculture practices. Agri. Syst. 173:151-160. https://doi.org/10.1016/j.agsy.2019.02.011

Jones, R., Hassell, D., Hudson, D., Wilson, S., Jenkins, G. 1., and Mitchell, J. (2003). Workbook on generating high resolution climate change scenarios using PRECIS. Hadley Centre for Climate Prediction and Research, Met Office, Bracknell, UK. 
Kagawa, M., and Bailey, C. (2006). Trade linkages in shrimp exports: Japan, Thailand, and Vietnam. J. Develop. Stud. 24(3):303-319.

Kam S.P., Badjeck, M.C., The, L., Nam, V. T.B., Hien, T. T., Hue, N. T., Phillips, M., Pomeroy, R., and Sinh, L.X. (2010). Economics of adaptations to climate change in Vietnam's aquaculture sector: A Case Study. Hanoi: World Bank.

Kam, S.P., Badjeck, M.C, The, L., The, L., and Tran, N. (2012). Autonomous adaptation to climate change by shrimp and catfish farmers in Vietnam's Mekong River Delta. Working paper 2012-24. Penang, Malaysia: WorldFish.

Kam, S.P., Teoh, S. J., Trinh, N. X., Tran, N., and Quyen, C. L. (2015). Vulnerability of the aquaculture sector in Vietnam to climate change: A Sub-National Assessment. Penang: WorldFish-CCAFS.

Kobayashi, M., Msangi, S., Batka, M., Vannuccini, S., Dey. M.M., and Anderson, J.L. (2015). Fish to 2030: the role and opportunity for aquaculture. Aquac. Econ. Manag.19(3):282-300.

Latka, C., Heckelei, T., Batka, M., Boere, E., Chang, C. Y., Cui, D., Geleijnse, M., Havlik, P., Kuijsten, A., Kuiper, M., Leip, A., van't Veer, P., Witzke, H. P., and Ziegler, F. (2018). SUSFANS Project H2020/SFS-19 - 2014: Sustainable food and nutrition security through evidence-based EU agro-food policy GA no. 633692. The potential role of producer and consumer food policies in the EU to Sustainable Food and Nutrition Security (Deliverable No. 10.3). http://edepot.wur.nl/464089>

Lehodey, P., Senina, I., Sibert, J., Bopp, L., Calmettes, B., Hampton, J., and Murtugudde, R. (2010). Preliminary forecasts of bigeye tuna population trends under the A2 IPCC scenario. Progress in Oceanography. 86:302-315.

Lehodey, P., Senina, I., Calmettes, B., Hampton, J., Nicol, S., Williams, P., Jurado-Molina, L., Ogura, M., Kiyofuji, H., and Okamoto, S. (2011). SEAPODYM Working Progress and Applications to Pacific Skipjack Tuna Population and Fisheries. $7^{\text {th }}$ regular session of the Scientific Steering Committee, 8-17 August 2011, Pohnpei, Federate States of Micronesia.

Maier, H.R., Guillaume, J.H., van Delden, H., Riddell, G.A., Haasnoot, M., and Kwakkel, J.H. (2016). An uncertain future, deep uncertainty, scenarios, robustness and adaptation: how do they fit together? Environ. Model. Softw. 81, 154-164. https://doi.org/10.1016/j. envsoft.2016.03.014.

Minderhoud, P.D.J., Coumou, L., Erkens, G., Middelkoop, H., and Stouthamer, E. (2019). Mekong delta much lower than previously assumed in sea-level rise impact assessments. Natu. Communi. 10:3847. 
Ministry of Agriculture and Rural Development (MARD). (2019). The summarization of aquaculture in 2019 the Mekong Delta, Vietnam and Planning for 2020. Annual Report (in Vietnamese).

Ministry of Agriculture and Rural Development (MARD). (2021). Online conference report with 28 coastal provinces to discuss solutions to develop the shrimp industry in 2021 and implement the Prime Minister's Decision No. 339/QD-TTg dated March 11, 2021 on approving the Development Strategy Developing Vietnam's fisheries to 2030, with a vision to 2045 (in Vietnamese).

Oborn, I., Bengtsson, J., Hedenus, F., Rydhmer, L., Stenstrom, M., Vrede, K., Westin, C., and Magnusson, U. (2013). Scenario development as a basis for formulating a research program on future agriculture: A methodological approach. AMBIO, 42:823-839. DOI 10.1007/s13280-013-0417-3

OECD/FAO. (2017). Fish in seafood. In: OECD-FAO Agricultural Outlook 2017-2026. OECD Publishing, Paris. https://doi.org/10.1787/agr_outlook-2017-12-en.

Oppenheimer, M., Glavovic , B.C., Hinkel, J., Wal, R. van de., Magnan, A.K., Abd-Elgawad, A., Cai, R., Cifuentes-Jara, M., DeConto, R. M., Ghosh, T., Hay, J., Isla, F., Marzeion, B., Meyssignac, B., and Sebesvari, Z. (2019). Sea level rise and implications for low-lying islands, coasts and communities. In: IPCC Special Report on the Ocean and Cryosphere in a Changing Climate [H.-O. Pörtner, D.C. Roberts, V. Masson-Delmotte, P. Zhai, M. Tignor, E. Poloczanska, K. Mintenbeck, A. Alegría, M. Nicolai, A. Okem, J. Petzold, B. Rama, N.M. Weyer (eds.)].

Popper, R. (2008). How are foresight method selected? Foresight. 10:62-89. http://dx.doi.org/10.1108/14636680810918586

Quyen, C. L., Cuong, H.V., Nam, P. H., Nghia, N.V., and Thanh, D.V. (2017). Climate change impact assessment on tuna fisheries in vietnam. WPEA project of sustainable management of highly migratory fish stocks in the West Pacific and East Asian Seas, Western \& Central Pacific Fisheries Commission (WCPFC).

Quyen, C. L., Hung, N.T., Chi, P. K., Lap, D.X., Dien, N.T., Thuy, V.V., Trang, P.T. and Tung, N.T. (2018). Impact assessment of climate change on shrimp farming to recommend technical and management improvement measures in shrimp production. Research report under the project "Developing a fair and sustainable shrimp value chain in Viẻtnam", Oxfarm Vietnam.

Quyen, C., Cuong, H., The, T., Thanh, P., and Van, D. (2019). Review and updated assessment of climate change vulnerability of aquaculture production in Agro-Ecological zones of Viet Nam. Final Activity Report 3 of the Project. 
Raskin, P., Monks, F., Ribeiro, R., Vuuren, D., and Zurek, M. (1995). Ecosystems and human wellbeing: scenarios, global scenarios in historical perspective.

Reilly M., and Willenbockel, D. (2010). Managing uncertainty: A review of food system scenario analysis and modelling. Philos Trans R Soc Lond B Biol Sci. 365(1554): 3049-3063. doi:10.1098/rstb.2010.0141

Rockmann, C., Ulrich, C., Dreyer, M., Bell, E., Rorodzicz, E., Haapasaari, P., Hauge, K.H., Howell, D., Mantyniemi, S., Miller, D., Tserpes, G., and Pastoors, M. (2012). The added value of participatory modelling in fisheries management - what has been learnt. Mari. Poli. 36 (5), 1072-1085.

Rosegrant, M.W., Sulser, T.B., Mason-D’Croz, D., Cenacchi, N., Nin-Pratt, A., Dunston, S., Zhu, T., Ringler, C., Wiebe, K., Robinson, S.,Willenbockel, D., Xie, H., Kwon, H. Y., Johnson, T., Thomas, T. S., Wimmer, F., Schaldach, R., Nelson, G. C., and Willaarts, B. (2017). Quantitative foresight modeling to Inform the CGIAR Research Portfolio. International Food Policy Research Institute (IFPRI), Washington DC, USA. http:// www.ifpri.org/publication/foresight-modeling-agricultural-research

Savo, V., Morton, C., and Lepofsky, D. (2017). Impacts of climate change for coastal fishers and implications for fisheries. Fish. Fish. 1-13. DOI: 10.1111/faf.12212

Senina, I., Lehodey, P., Smith, N., Hampton, J., Reid, C., and Bell, J. (2018). Impact of climate change on tropical tuna species and tuna fisheries in Pacific Island waters and high seas areas. Final Report (CI-3) for SAN 6003922.

Suri, H. (2011). Purposeful sampling in qualitative research synthesis. Qualit. Resea. J. 11(2).

Te, B. Q. (2003). Shrimp diseases and treatments. Agriculture Publications, Hanoi. Japan International Cooperation Agency (JICA), Adaptation to climate change for sustainable development of agriculture and rural in Coastal Area of Mekong River Delta.

The Government of Vietnam, Resolution No.09/2000/NQ-CP of June 15, 2000 on a number of undertaking and policies on economic restructuring and consumption of farm produce, Hanoi, Vietnam 2000.

Thuc, T., Thang, N.V., Huong, H.T.L., Khiem, M.V., Hien, N.X., and Phong, D.H. (2016). Climate change and sea level rise scenarios for Vietnam. Ministry of Natural Resources and Environment, Hanoi.

Tran, N., Bailey, C., Wilson, N., and Phillips, M. (2013). Governance of global value chains in response to food safety and certification standards: The case of shrimp from Vietnam. Wor. Develop. 45(2013) 325-336. http://dx.doi.org/10.1016/j.worlddev.2013.01.025

Tran, N., Rodriguez, U. P., Chan, C. Y., Phillips, M. J., Mohan, C. V., Henriksson, P. J. G., Koeshendrajana, S., Suri, S., and Hall, S. (2017). Indonesian aquaculture futures: An 
analysis of fish supply and demand in Indonesia to 2030 and role of aquaculture using the AsiaFish model. Mari. Poli. 79:25-32. https://doi.org/10.1016/j.marpol.2017.02.002

827 Tran, N., Chu, L., Chan, C. Y., Genschick, S., Phillips, M. J., and Kefi, A. S. (2019). Fish supply 828 and demand for food security in Sub-Saharan Africa: An analysis of the Zambian fish sector. Mari. Poli. 99:343-350. https://doi.org/10.1016/j.marpol.2018.11.009

830 Urch, M. (2016). Vietnam's tuna exports rise, With Israel a potential new market. September 30, 2016. Seafood Source. https://www.seafoodsource.com/news/supply-trade/vietnam-s-tuna-

833 Vietnam Association of Seafood Exporters and Producers. (2018). Statistics of the fisheries sector 834 in the period of 2010-2018.

835 Vietnam Institute of Meteorology, Hydrology and Climate Change. (2010). Impact of climate change on water resource and adaptation measures in Mekong River delta.

837 World Bank. (2013). Fish to 203: Prospects for fisheries and aquaculture. Agriculture and 838 Environmental Services Discussion Paper 03. Washington, DC. World Bank. https://openknowledge.worldbank.org/handle/10986/17579 License: CC BY 3.0 IGO. 


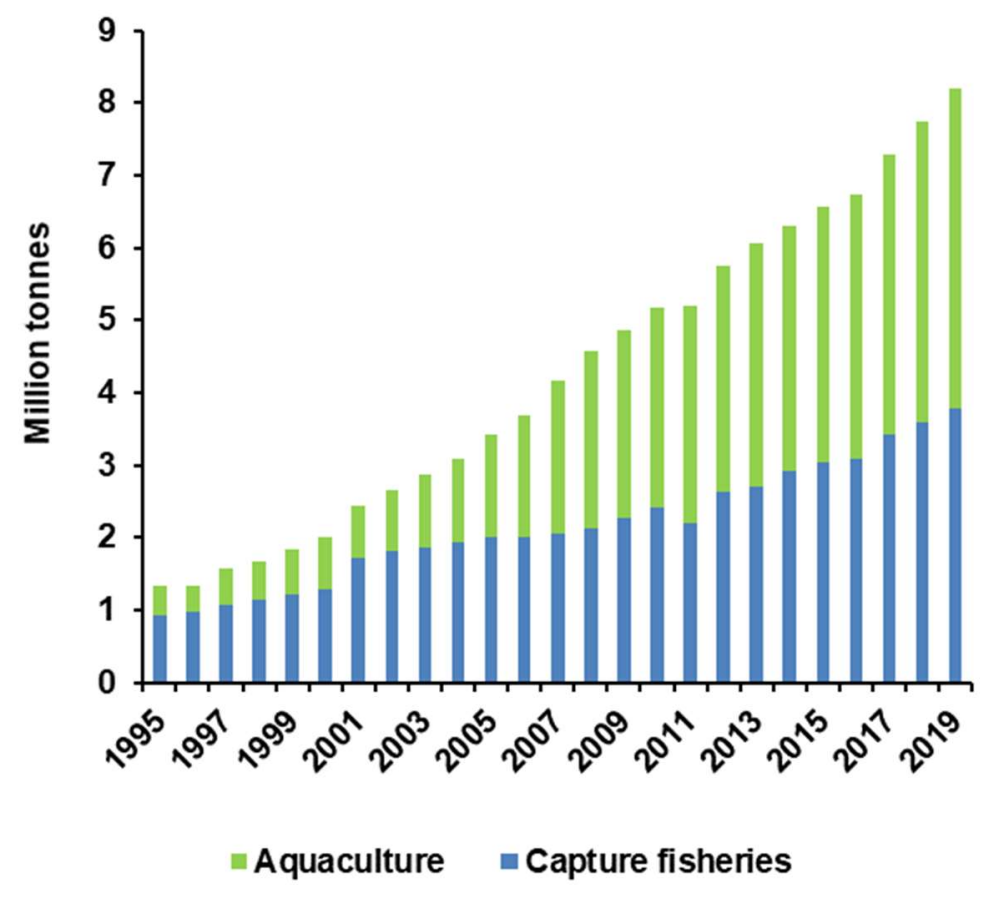

841

842 FIGURE 1: Aquaculture and capture fisheries production in Vietnam, 1995-2019

843 Data source: General Statistics Office (GSO), 2018; Directorate of Fisheries, 2017, 2018 and 2019. 844

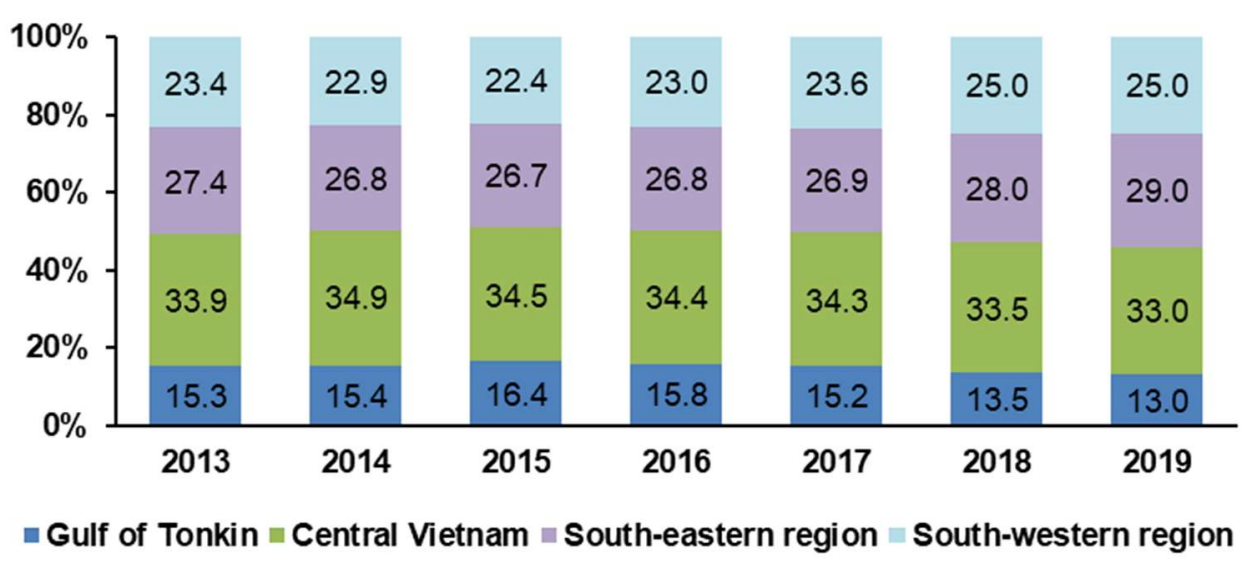

846 FIGURE 2: Proportion of regional marine landings in Vietnam, 2013-2019

847 Data source: General Statistics Office (GSO), 2018; Directorate of Fisheries, 2017, 2018 and 2019 848 


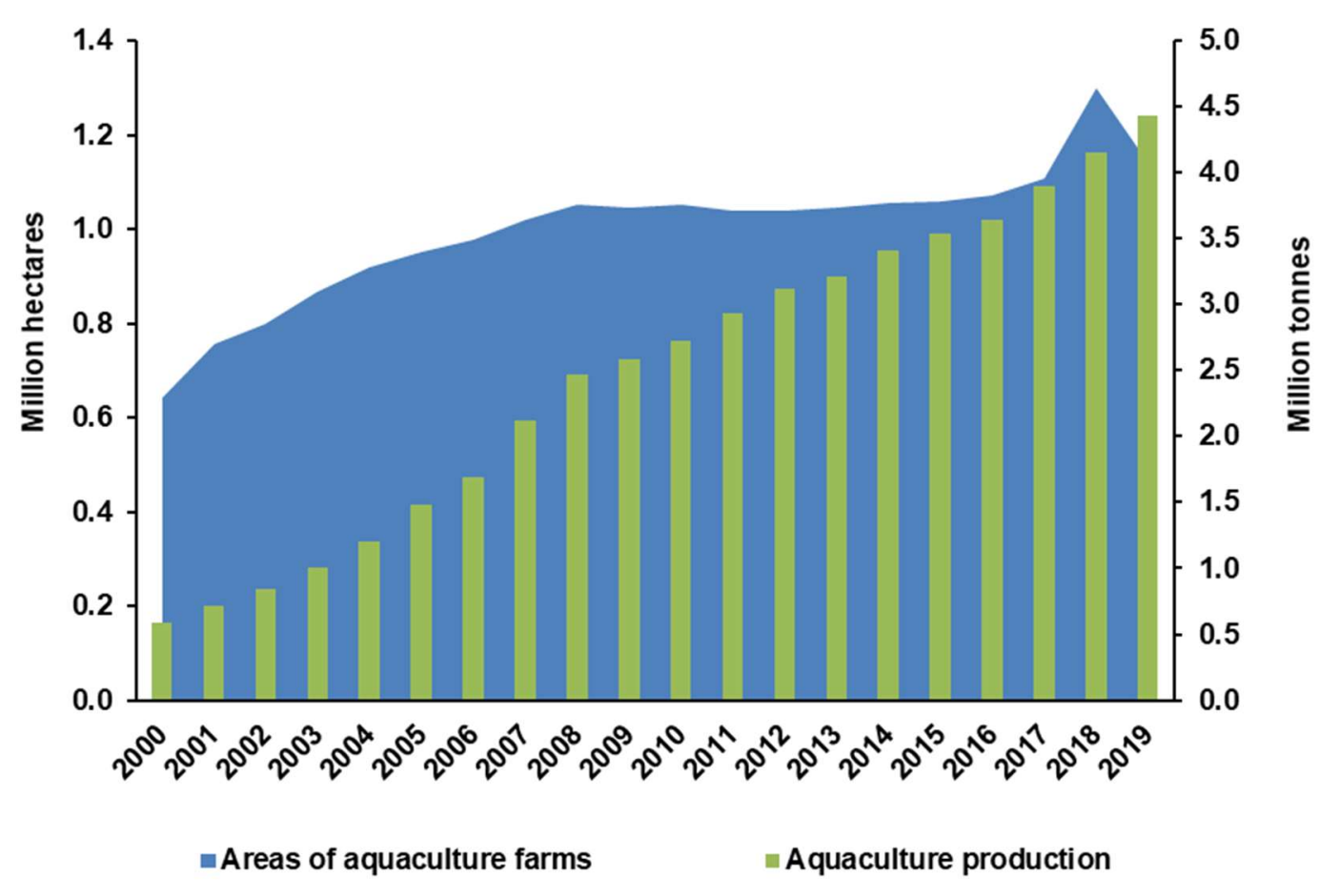

849

850

851 FIGURE 3: Areas of aquaculture farms and aquaculture production in Vietnam, 2000-2019

852 Data source: General Statistics Office (GSO), 2018; Directorate of Fisheries, 2017, 2018 and 2019 853 


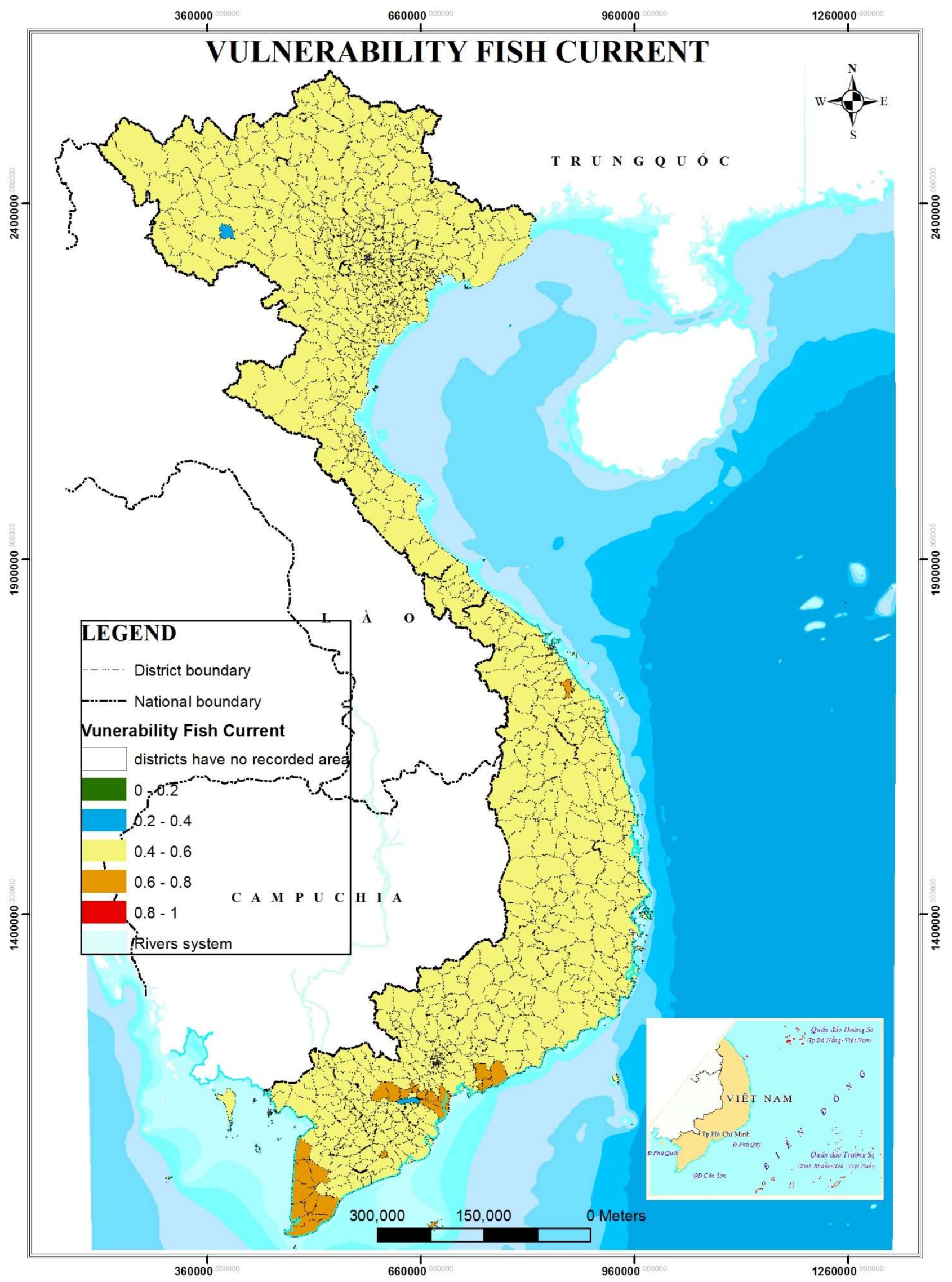

856 FIGURE 4: Vulnerable level of fish farming to climate change

Source: Quyen et al. (2018) 


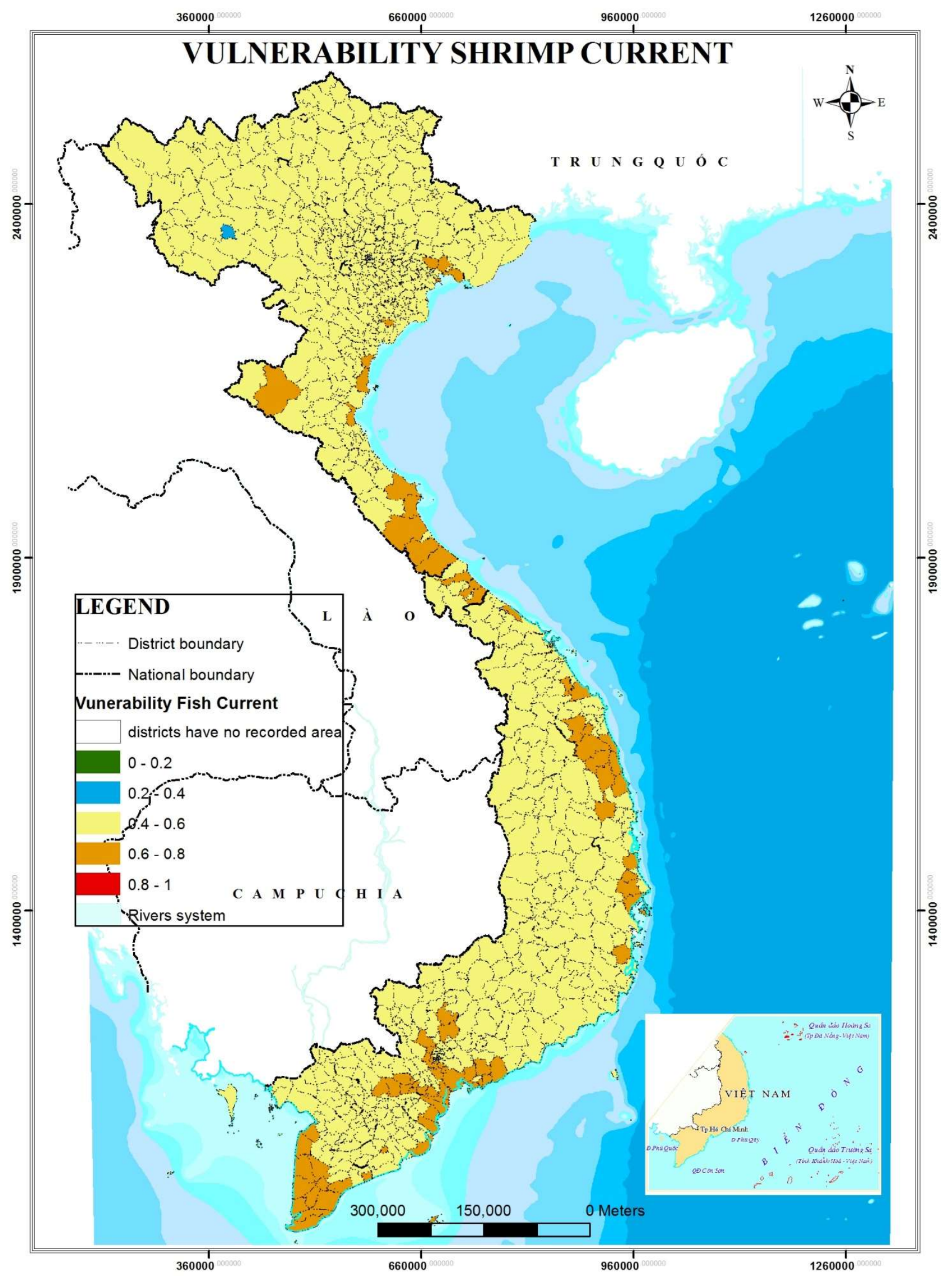

FIGURE 5: Vulnerable level of shrimp farming to climate change

860 Source: Quyen et al. (2018) 